\title{
Hurricane-induced mass mortalities to a tropical subtidal algal community and subsequent recoveries
}

\author{
David L. Ballantine \\ Department of Marine Sciences, University of Puerto Rico, Mayaguez, Puerto Rico 00708
}

\begin{abstract}
Hurricanes David (Aug 1979) and Allen (Aug 1980) caused extensive mass mortalities in a subtidal benthic algal community. The area studied lies offshore from the southwest corner of Puerto Rico, in $17 \mathrm{~m}$ of water, and normally supports a rich algal flora. Recolonizations proceeded with continual accumulation of species; at the scale examined, recruitment appeared to be a random process. Competitive displacement of initial colonizing species was not observed, and recoveries were qualitatively considered to be complete within $1 \mathrm{yr}$ of the disturbances.
\end{abstract}

\section{INTRODUCTION}

In 1979 and 1980, the Caribbean Hurricanes David and Allen caused mass mortalities in an offshore algal plain in the vicinity of La Parguera on the southwest coast of Puerto Rico. Hurricane damage to marine benthic communities has been reported previously. Most accounts have dealt primarily with mortalities suffered by coral reefs (Stephenson et al., 1958; Glynn et al., 1964; Goreau, 1964; Ball et al., 1967; Stoddart, 1970; Porter, 1974; Ogg and Koslow, 1978; Woodley et al., 1981; Rogers et al., 1982, 1983). By contrast, there are few reports concerning hurricane-induced mortalities in marine benthic algal communities. Glynn et al. (1964), however, made brief mention of mortalities to local reef flat algal populations in Puerto Rico following Hurricane Edith in 1963. Matta (1981) reported a decline in abundance and species numbers in the benthic algae of a shallow water lagoon and reef habitat in the wake of Hurricane David.

Recolonization of marine algal communities has been widely studied. Most studies have dealt with intertidal, largely temperate, communities (e.g. Menge, 1976; Emerson and Zedler, 1978; Lubchenco and Menge, 1978; Murray and Littler, 1978; Niell, 1979; Sousa, 1979). There are considerably fewer reports of recolonization in subtidal areas (Tsuda and Kami, 1973; Foster, 1975; Kain, 1975; Neushul et al., 1976; John et al., 1977); only Tsuda and Kami (1973) and John et al. (1977) deal with tropical floras.
The work reported here documents mass mortalities caused by hurricanes to a tropical subtidal algal community and subsequent recoveries. The occurrence of Hurricane Allen 1 yr after Hurricane David allowed the opportunity to make repetitive observations on recolonization and to compare community development. While little is known of tropical benthic subtidal algal communities, studies of recolonization help to provide insight into recruitment, community development, and dynamics.

\section{STUDY SITE AND METHODS}

The algal community studied lies $5 \mathrm{~km}$ offshore from La Parguera (approximate coordinates: $17^{\circ} 55^{\prime} \mathrm{N}_{i}$ $67^{\circ} 30^{\prime} \mathrm{W}$ ) in $17 \mathrm{~m}$ of water. The benthic habitat is referred to as 'rastrail' (a plain) by local fishermen due to its flat and level character. Bottom sediments are primarily biogenic sand composed of mollusc fragments, Halimeda plates, coral fragments, and - to a lesser degree - fragments of coralline algae (Morelock, 1977). This substrate typically supports the growth of numerous siphonaceous chlorophyte genera including Caulerpa, Halimeda, Penicillus and Udotea, as well as of the seagrass Halophila decipiens. Numerous other macrophyte species also populate limestone and coral rock as well as shell and coral fragments. The flora is rich in composition; Ballantine (1977) reported over 200 algal species, including epiphytes. 
In order to evaluate recoveries of the offshore algal flora, a series of permanent quadrats were laid out by SCUBA divers following Hurricane David. This allowed observations at exactly the same sites during recoveries. An area within the algal plain known to support a rich algal community was selected. Four quadrats (designated as A, B, C and D) were linearly separated by a distance of approximately $5 \mathrm{~m}$, with the initial quadrat (A) randomly positioned by throwing a $1 \mathrm{~m}^{2}$ metal frame from the surface. Each quadrat was subdivided into four $1 / 4 \mathrm{~m}^{2}$ subquadrats whose perimeters were defined with polyethylene line. At each sampling, two $1 / 4 \mathrm{~m}^{2}$ subquadrats, chosen arbitrarily from each of quadrats $A$ to $D$, were examined. Thus a total of eight subquadrats (total area $2 \mathrm{~m}^{2}$ ) were censused per sampling period. The same subquadrats were sampled repeatedly at approximately 2 to $4 \mathrm{wk}$ intervals. Bottom substrate was generally homogenous and therefore, samples were considered to be of the same community.

Sampling was done using SCUBA and was nondestructive. Taxa present were recorded by visual census and species surveyed were thus restricted to macroscopic plants which could be identified in situ by a diver. In some cases, plants could only be identified to the generic level in this manner. Nomenclature follows Almodóvar and Ballantine (1983).

Frequency of algal species present at each sampling was calculated on the basis of the fraction of the observed eight subquadrats that contained those species. Comparison of recolonization processes was based on presence/absence data for comparable sampling periods utilizing the similarity coefficient of Sørensen (1948) where:

$$
\mathrm{S}=\frac{2 \mathrm{C}}{\mathrm{A}+\mathrm{B}}
$$

where $\mathrm{S}=$ similarity coefficient; $\mathrm{A}=$ number of species in Sample a; B = number of species in Sample b; $C=$ number of species common to $a$ and $b$. Samples $\mathrm{a}$ and $\mathrm{b}$ correspond to the species make up of any 2 individual subquadrats or pooled subquadrats compared to each other.

Cluster analysis utilizing single linkage dendrograms (Everit, 1980) and polar ordination (Bray and Curtis, 1957) were employed to detect possible relations among samples. For purposes of these statistical analyses, each quadrat $(\mathrm{A}, \mathrm{B}, \mathrm{C}, \mathrm{D})$ was treated as a single sample with the $1 / 4 \mathrm{~m}^{2}$ subquadrat data pooled. Dendrograms were constructed from matrices of similarity indices calculated from data taken at ten sampling periods. Sampling was at comparable times following each hurricane.

\section{RESULTS}

\section{Hurricane effects}

On August 30,1979, Hurricane David passed $129 \mathrm{~km}$ to the south of Puerto Rico. David, touted as the most intense hurricane of this century in the eastern Caribbean, generated sustained winds of $86 \mathrm{~km} \mathrm{~h}^{-1}$ (Anonymous, 1980) and waves that were locally estimated to be $6 \mathrm{~m}$ in height. Nearly 1 yr later (4 Aug 1980), Hurricane Allen passed $340 \mathrm{~km}$ to the south of La Parguera. Allen also generated seas that were estimated to be in the range of $6 \mathrm{~m}$ in height. Fig. 1 shows the tracks of Hurricanes David and Allen in the Caribbean. Both

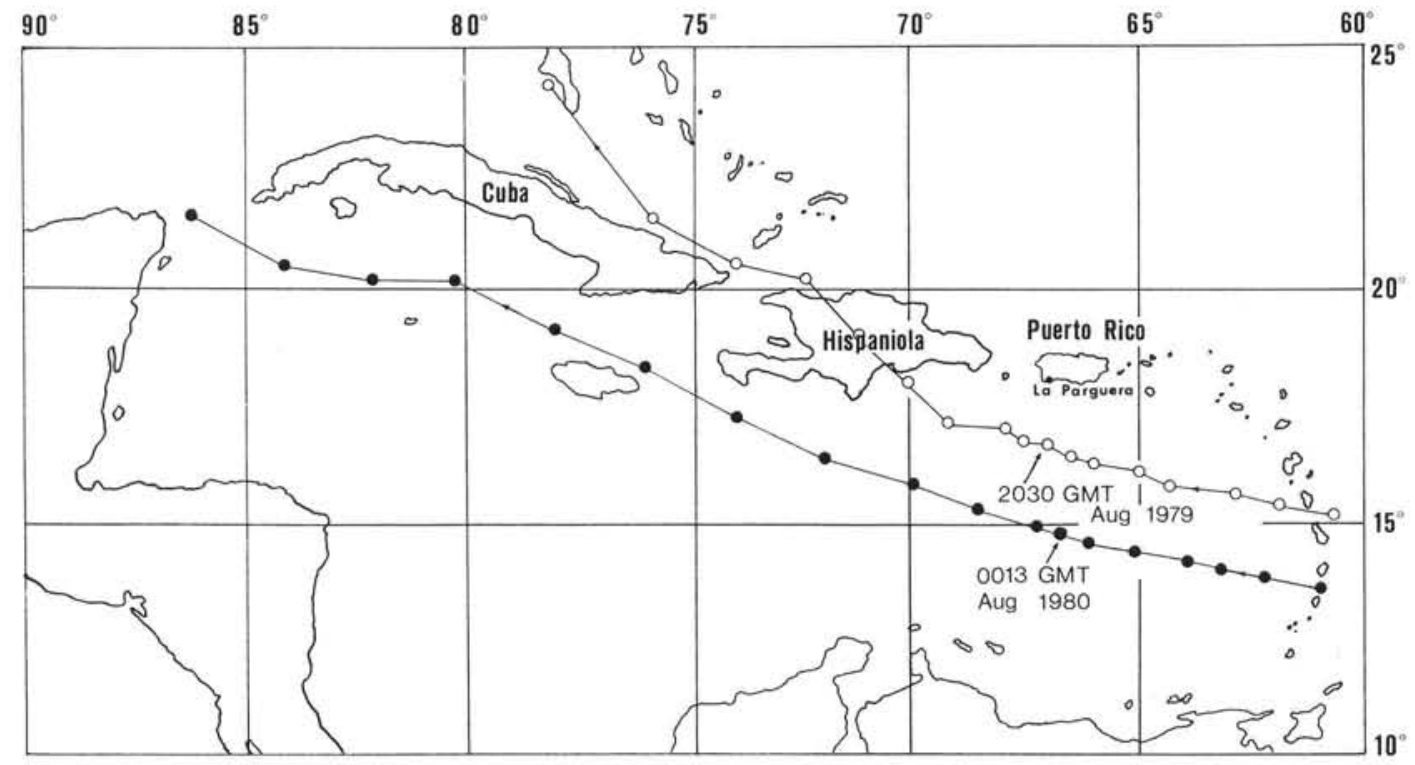

Fig. 1. Paths of Hurricanes David $(O)$ and Allen $(\bullet)$ through the Caribbean in August 1979 and 1980. Arrows: direction of hurricane passage. GMT: Greenwich mean time 
hurricanes were responsible for considerable damage to inshore coral reefs, as well as for mass mortalities to offshore benthic algae. At the site studied, the overall result following both hurricanes was near-complete destruction of the entire flora. Hurricane-induced deaths were undoubtedly due to a combination of factors which include: (1) currents and turbulence which dislodged algae from their substrate; (2) sand abrasion; (3) smothering due to burial by sand. Large barren waves of sediment (Fig. 2) with occasional par-

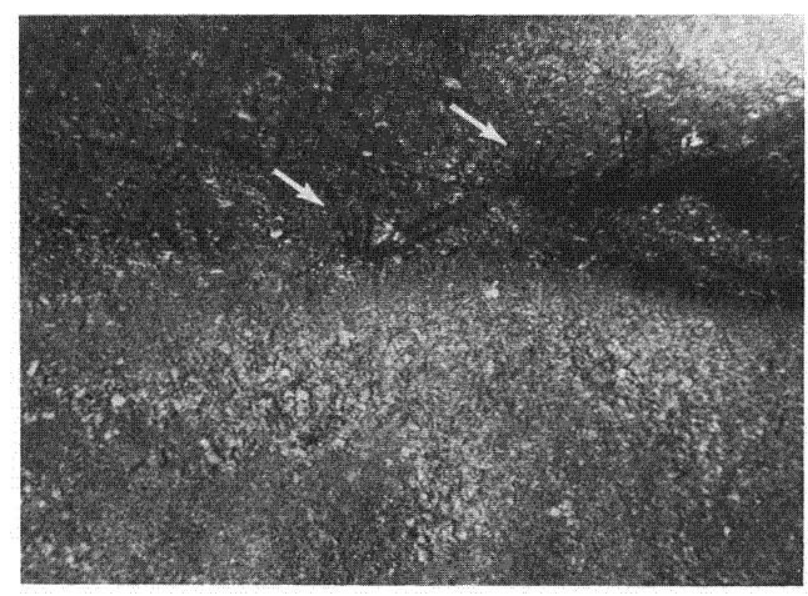

Fig. 2. Bottom habit after passage of Hurricane David (1979). Waves of sediment indicate considerable sediment displacement. Arrows: partially buried Gracilaria sp.

tially buried macrophyte algae characterized the bottom after each hurricane.

Large amounts of fine sediment suspended by turbulent water apparently settled over the more typical coarse sediment when sea conditions calmed. While size fractions of surface sediment were not measured, they were much finer than before the hurricanes. The few plants which survived were generally buried in sediment to depths ranging from 2.5 to $15 \mathrm{~cm}$ from their holdfasts. The partial burial of surviving algae resulted in severe shading of lower thallus portions. Within several weeks, the buried portions of individually monitored plants had become necrotic and most above-sediment thalli had broken off. Many of the plants, initially assumed to be survivors, were thus subsequently lost to the community as well.

Those few plants which did survive were mostly coarse red algae, including Bryothamnion triquetrum, Laurencia poitei and Gracilaria spp. Even these more resistant plants survived only in low numbers. Surviving but less prevalent than the above-mentioned algae were Digenia simplex, Enantiocladia duperreyi, Chondria floridana, and Sargassum spp. A few individuals of Codium isthmocladum were also found following Hurricane David and these were badly abraded by sand. The surviving algae were nearly completely devoid of epiphytes despite the fact that many of the above species normally support heavy epiphytic growth (Ballantine, 1979). The only common epiphyte present was Fosliella farinosa and its crustose form probably prevented its being scoured off by sand. The very few other epiphytic species present averaged less than $1 \%$ coverage on their hosts.

\section{Recolonization}

The term recolonization is used in a broad sense including both initial colonization and subsequent recovery. Recolonization proceeded from a nearly totally denuded condition. It was assumed that few spores or propagules could have remained viable due to severe scouring and burial. Percent cover by algae was initially estimated to be less than $1 \%$ in all quadrats. Approximately $1 \mathrm{wk}$ after both disturbances, a fine film of diatoms was observed which covered the bottom in the general vicinity of the study site. This mat disappeared prior to the appearance of recolonizing macroalgal species. Due to reworking of the bottom sediments by the hurricanes, which resulted in fine sediments overlying coarse sediments, recolonization was probably intially slowed until natural sorting provided coarse material at the sediment surface which would be suitable for attachment of benthic algal species. A number of algal species were observed attached to small pebbles or shell fragments. When these colonizing plants surpassed as size threshold (due to resistance against current motion), they essentially became part of a drift population. On several occasions, such plants entered and left a given quadrat during the observation period. This situation was especially common during the first months of recolonizations.

During the first month following both hurricanes, only a few colonizing species were recorded. A Botryocladia species (description as a new species in progress), Champia parvula, C. compressa, and Dictyota spp. were among the earliest colonizers, appearing within the first 3 wk. A number of small plants of Udotea spp. also were observed during the first month of recolonization. In this case, it is not known whether they were initiated from spores or resulted from vegetative growth by stolons from still buried plants. Surviving species such as Laurencia poitei and Chondria floridana showed proliferous growth which probably originated from injured tissue. Only several small individual plants of Pseudobryopsis duchassaignii were encountered immediately following Hurricane David. This is in contrast to massive blooms of $P$. duchassaignii in shallow water reef habitats which covered broken coral and other available substrate. This bloom 
condition persisted for 2 mo in shallow water areas (Matta, 1981). Recolonization curves showing accumulation of total identified species from 8 subquadrats recorded after both hurricanes are shown in Fig. 3.

Possible relations involving groups of samples taken during recolonizations were examined by dendrogram analysis (Fig. 4). In this figure, for the first recolonization, quadrat numbers were assigned so that smallest numbers correspond to earliest recolonization and larger numbers to later recolonization periods. No discrete clusters were apparent but the large majority of samples were linked by small differences in similarity.
This was also the case for the second recolonization (not illustrated). There was greater concordance in species composition within individual quadrats from one sampling to the next (i.e. quadrats $1,5,9$, etc.; 2,6 , 10 , etc. ; $3,7,11$, etc.; $4,8,12$, etc.) than among quadrats sampled at the same time [ $\overline{\mathrm{S}}$ (among all first recolonization individual quadrats between consecutive samplings) $=.67>\overline{\mathrm{S}}$ (among all first recolonization quadrats sampled at same time) $=.44 ; \mathrm{P}<.001]$. This relation also held for the second recolonization.

Similarity data were additionally analyzed utilizing polar ordination in one dimension, and ordination

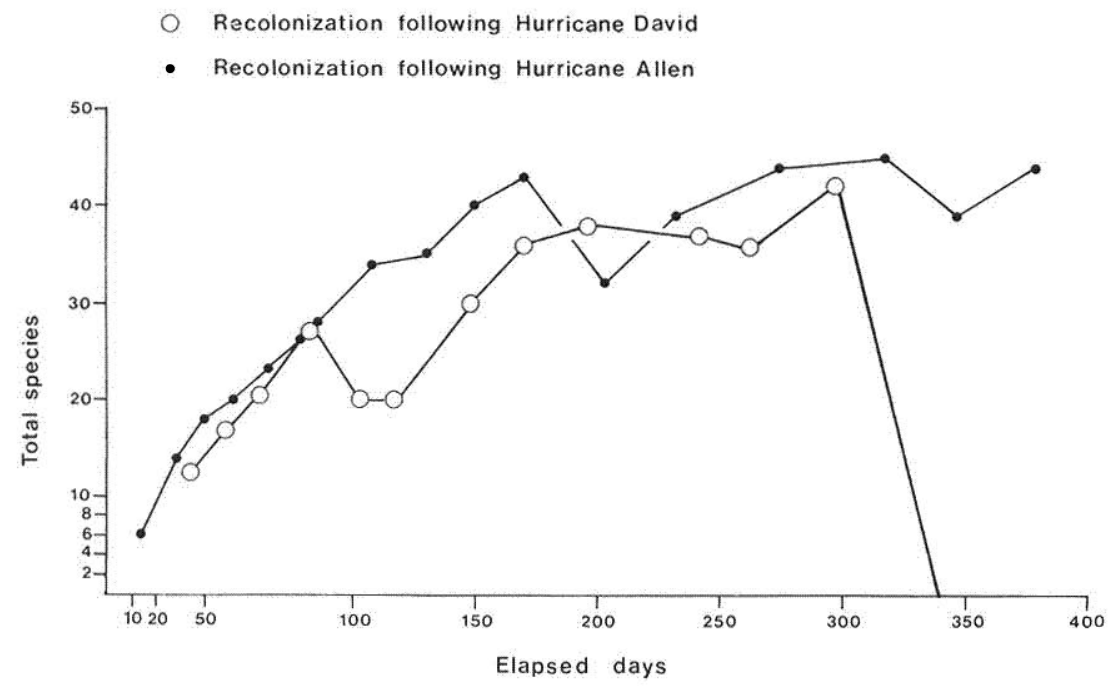

Fig. 3. Accumulation of macrophyte algal species following Hurricanes David and Allen, from combined quadrats $\left(2 \mathrm{~m}^{2}\right)$

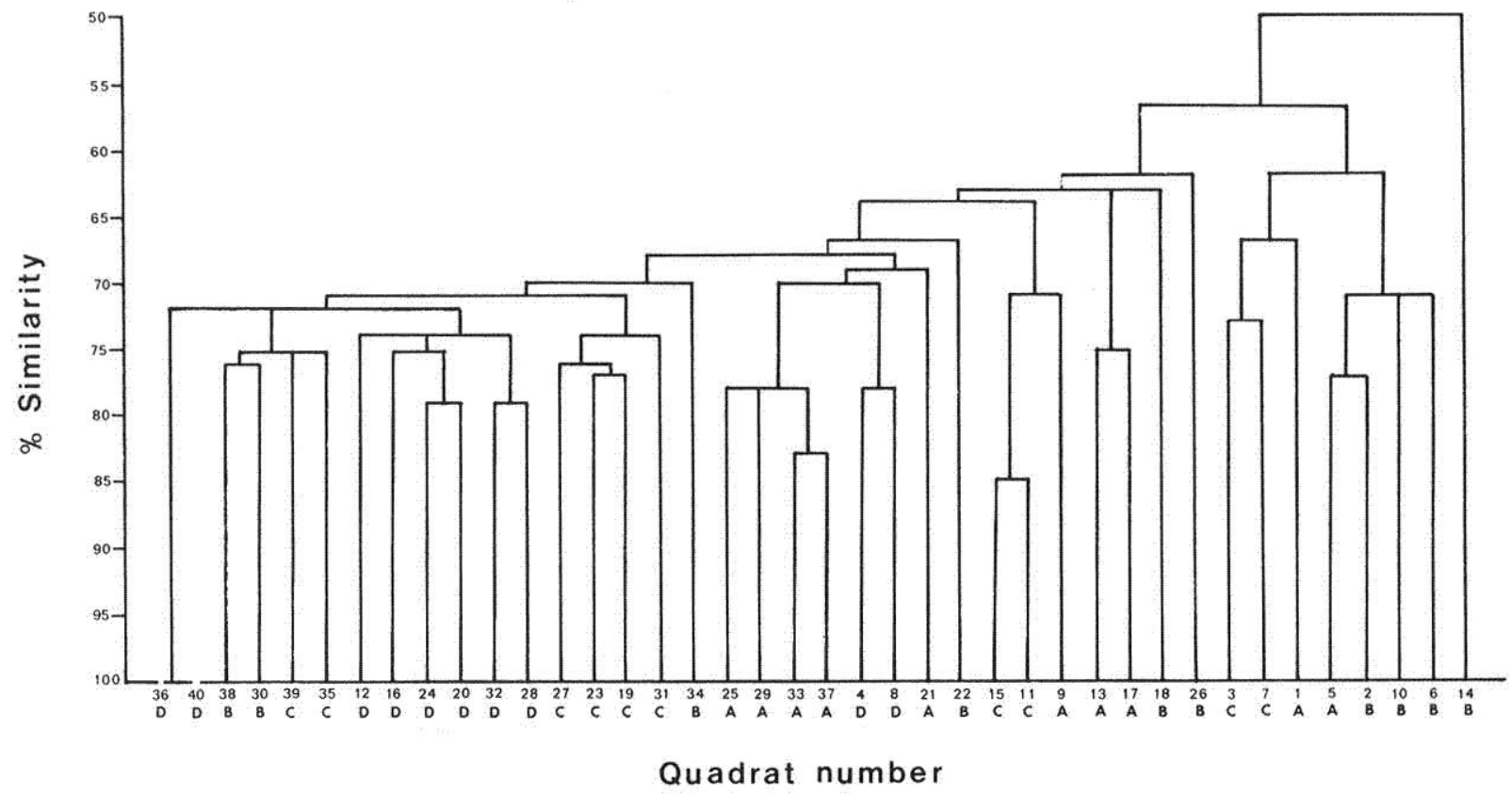

Fig. 4. Single linkage dendrogram showing relations of species composition among 40 quadrats sampled at 10 intervals following Hurricane David. Quadrats 1 to 4, 34 elapsed days from date of hurricane; Quadrats 5 to 8, 48 elapsed days; Quadrats 9 to 12,82 elapsed days; Quadrats 13 to 16, 103 elapsed days; Quadrats 17 to 20, 148 elapsed days; Quadrats 21 to 24,170 elapsed days; Quadrats 25 to 28, 197 elapsed days; Quadrats 29 to 32, 242 elapsed days; Quadrats 33 to 36, 263 elapsed days; Quadrats 37 to 40 , 297 elapsed days. A, B, C, D: specific quadrats sampled 
Fig. 5. Polar ordination of samples taken during recolonization following Hurricane David. Position of quadrat numbers were established by striking arcs with radii equal to dissimilarity distance (1 S) from the most dissimilar quadrats, no. 1 and 27 respectively. Position defining arcs are shown for Sample 9. Vertical dotted line: Projection to abscissa

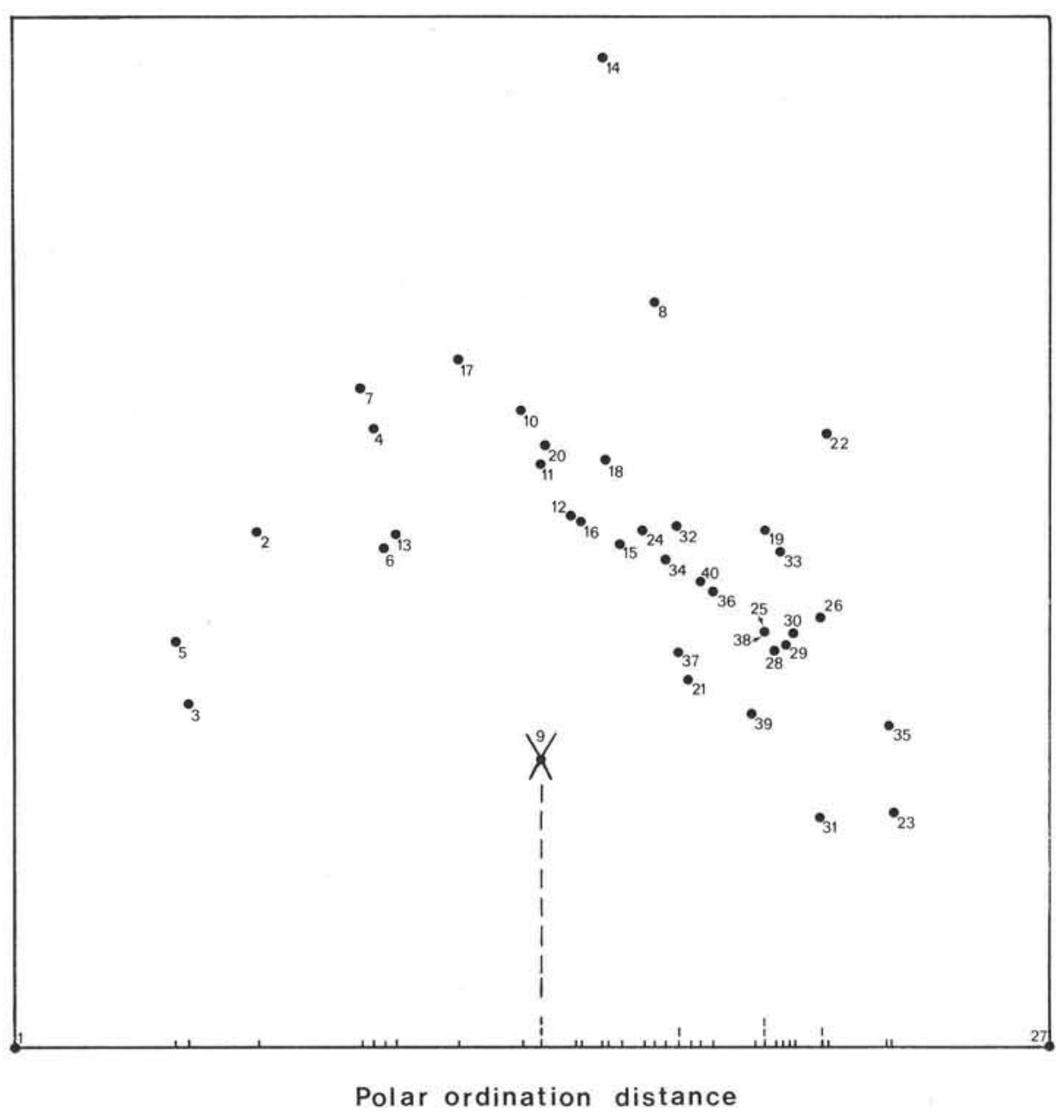

among samples taken during the first recolonization is shown in Fig. 5. When sample numbers are projected to the abscissa, an ordering along a single gradient results. If the abscissa corresponds to a temporal axis, the sequence of sample numbers along it should correlate with the numerical sequence of sample numbers. This was found to be the case as calculation of Spearman rank correlation coefficients demonstrated significant $(\mathrm{P}<.01)$ correlations for both recolonizations.

\section{Comparison of recolonizations}

A total of 74 algal species were identified during both recolonizations. Fifty-five of these were common to both and the similarity index calculated for all species between recolonizations was high $(\overline{\mathrm{S}}=.85)$. In terms of numbers of species present after 10 and $12 \mathrm{mo}$, the recolonizations were essentially the same. Fortytwo species were present following 10 mo recolonization after Hurricane David and 44 species were present after $1 \mathrm{yr}$ following Hurricane Allen. Recolonization curves (Fig. 3) also show similarity in the pattern of accumulation of species through time. This, however, does not take into account similarities or differences in species involved. Recolonizations were therefore compared as to degree of similarity of species composition. Indices of similarity were calculated among quadrats of equivalent time of recolonization for 8 sampling periods. The overall average index of similarity for all 128 possible combinations of comparable quadrats was low $(\overline{\mathrm{S}}=.44)$ and not significantly different $(\mathrm{P}<.01)$ from a similarity index calculated for random pairs of quadrats between recolonizations. This indicates no greater degree of comparability than would be expected by chance alone.

Kite diagrams showing frequency of occurrence of 30 species selected as representative are presented in Fig. 6 . The frequency distribution of species through time following both disturbances are in some cases highly similar (e.g. Acanthophora spicifera, Bryothamnion triquetrum, Neomeris annulata, Sargassum spp.). Other frequency distributions are dissimilar, with some species present in one recolonization and absent in the other. Still other species were sporadic in their appearance during the course of study (e.g. Champia com- 

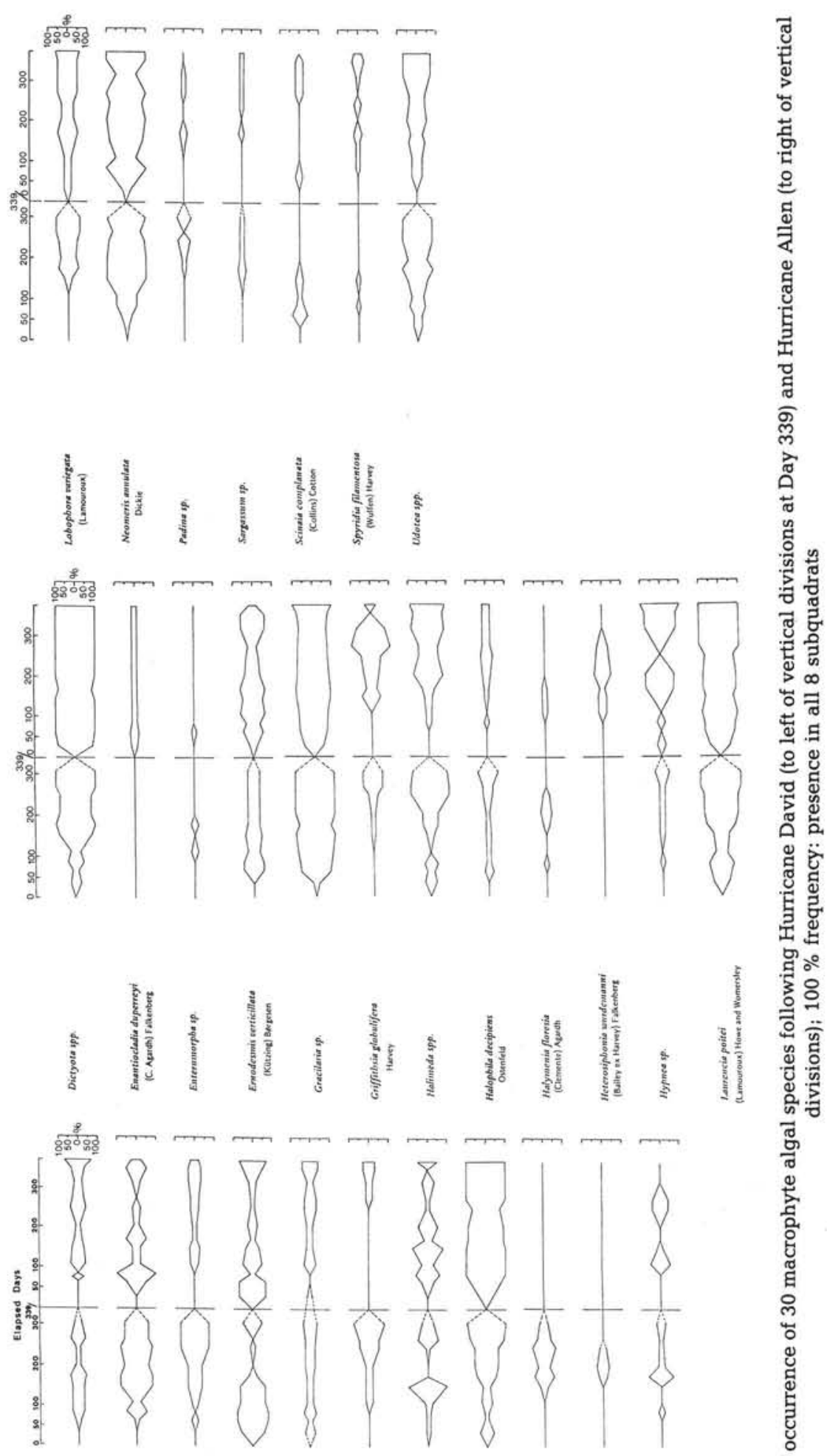

ฮี

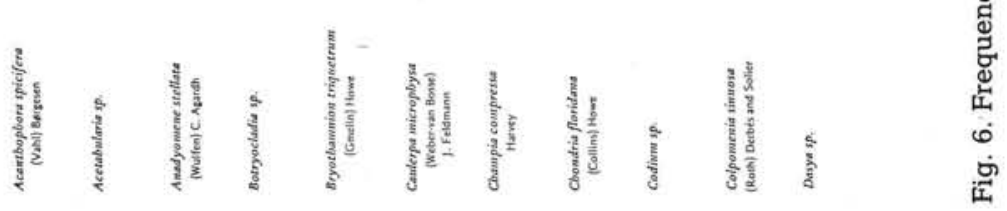


pressa, Dasya sp., Enteromorpha sp., Halymenia floresia, Padina sp., Scinaia complanata, Botryocladia sp.).

\section{DISCUSSION}

Hurricanes David and Allen caused extensive mass mortalities to a deep-water tropical algal community. Dendrogram analysis demonstrated that recolonization was not characterized by discrete clustering of samples. Results suggest that through time, recolonization proceeds gradually with the continual addition of some species and the occasional loss of others. A high percentage of the species that initially appeared as colonizers was also present after 1 yr. Conversely, the most abundant species in terms of frequencies after 1 yr were also commonly among the initially occurring species. Species such as Botryocladia sp. and Champia spp. were uneven in their temporal occurrence, being very abundant at times and absent at others. These species reproduce rapidly and then die. The fact that they were among the initial colonizers and still abundant at later stages is probably a simple reflection of the number of spores in the water at a particular time. Their later appearance is thus apparently not inhibited by competition with established species, and their occurrence is therefore not limited to a pioneer status during recovery. Any highly vagile species should be continuously well represented in the community (e.g. Dictyota spp., Laurencia poitei, Neomeris annulata; Fig. 6). Species with proportionately fewer spores in the water would not be expected to occur until later in the recolonization process due to probability alone. This does not mean that these species are incapable of establishing early, but that their probability of doing so is reduced. The appearance of a recolonizing species at any successional stage in this deep water tropical community thus appears to be more dependent on its life history characteristics and the vagaries of currents than on biologically controlled deterministic factors.

As 'pioneer' species appear not to be competitively displaced, similarly the loss of the other species that invariably occurs (Fig. 6) is probably more related to life history characteristics of plants involved than replacement due to competitive interactions. The initial colonizing diatom film on the sediment surface also disappeared without apparent competitive interaction with subsequent macrophyte species. This disappearance may have been related to change in sediment size at the sediment surface due to natural sorting. Individual species appear to be independently distributed and their appearance is interpreted to be a stochastic event at the scale examined.

Essentially the same general pool of species was identified during the course of each recolonization and both recolonizations were initiated at the same time of year, eliminating possible differences due to seasonal effects. Despite this, a dissimilarity in recolonization events following both hurricanes is indicated by the fact that the concordance of similarities among quadrats sampled at the same time did not differ significantly from similarities among randomly selected pairs of quadrats. Dissimilarity between recolonizations would be expected if species are independently distributed as suggested above.

There has been disagreement regarding the concept of succession as it applies to marine algal community development. If recolonization involves the appearance of groups of species which are subsequently replaced by later groups of species, this would imply competitive interactions which are not in evidence here. The pattern of recolonization described in this study therefore differs from the classical facilitation model of succession, which in fact is rarely applicable to marine situations (Connell and Slatyer, 1978). Rather, it has some elements in common with the tolerance model (Connell and Slatyer, 1978) in which modification of the environment brought about by early colonizers neither increase nor decrease rates of recruitment of subsequent species. This model ultimately predicts that slow growing, larger species will eventually predominate through competition. The latter was not observed in the present study which indicates that either one year is insufficient time to attain a 'climax' community or that such a community is not attained. On the basis of 8 previous years of qualitative observations of species abundance and biomass, however, recovery was considered to be complete and comparable to pre-hurricane status following 1 yr (Fig. 7). Tsuda and Kami (1973) also reported attainment of a subtidal algal climax community after only one $1 \mathrm{yr}$ in tropical Guam. Considerably longer periods of time for the attainment of algal climax communities have been reported for temperate water situations, with periods of 3 to 6 yr common (Kain, 1975; Foreman, 1977). Sears (1982) found that after $4 \mathrm{yr}$, less than $10 \%$ recovery had occurred following denuding patches in a deep water algal community from the Gulf of Maine.

The development process described here for a tropical subtidal algal community also differs considerably from temperate intertidal or subtidal situations in which communities may become dominated by a single or several predicted species. While recovery may be considered complete, there was no stable climax characterized by domination by a few species. The community in likelihood is maintained in a nonequilibrium condition (Connell, 1978). The benthic habitat may be envisioned as a mosaic of microhabitats with a spectrum of different size substrates ranging from substantial limestone outcropping to intermedi- 


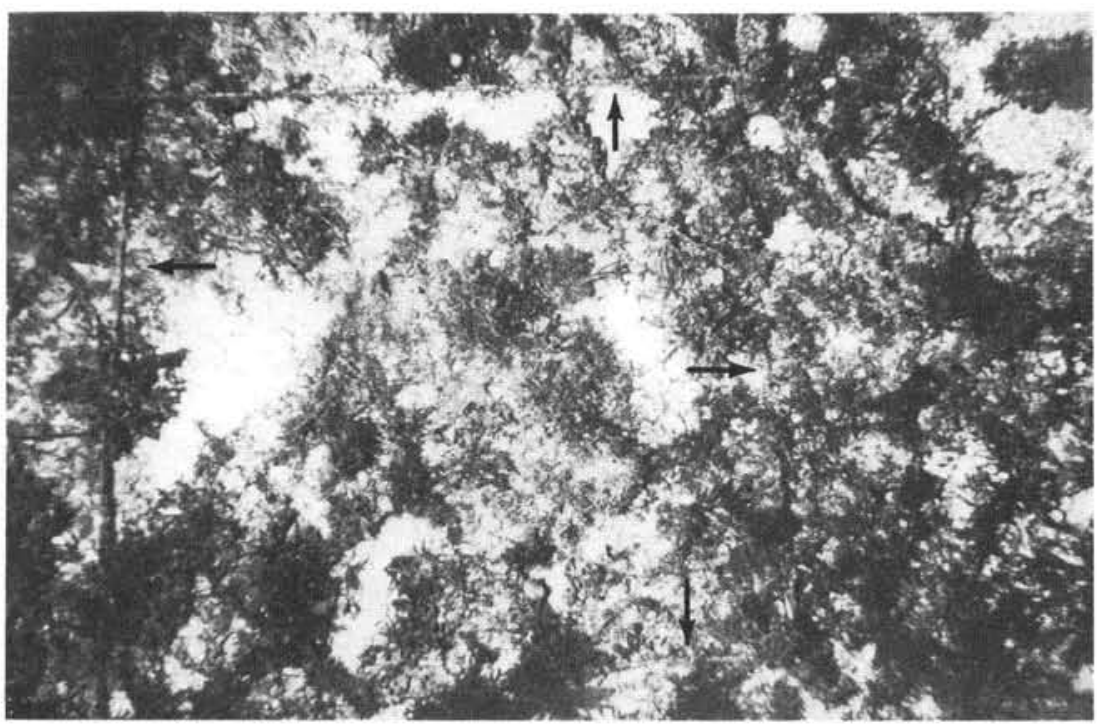

Fig. 7. $1 / 4 \mathrm{~m}^{2}$ quadrat $(8-17-81) 378 \mathrm{~d}$ following Hurricane Allen. Recolonization is considered complete following 1 yr of recovery. Arrows: lines defining quadrat perimeter.

\section{LITERATURE CITED}

ate and small coral and shell fragments. These are varying in stability and subject to shifting due to the effects of natural disturbances such as storms of varying intensities. This situation is analagous to a low intertidal boulder field described by Sousa (1979) in which stochastic disturbances periodically renew limiting resources, in this case space. Paine and Levin (1981) have pointed out that communities subject to intermediate levels of disturbance may thus maintain a high diversity.

In addition to storms, other disturbances occur. Approximately 6 mo after termination of taking data in 1981, a population explosion of Diadema antillarum occurred. These urchins grazed the abundant macroalgae to a point where the benthic community was reduced to a low turf and large areas of the bottom were essentially denuded. This condition is reminiscent of 'urchin barrens' as described for temperate waters (Paine and Vadas, 1969; Breen and Mann, 1976). Beginning in 1983, an epidemic resulting in mass mortalities of $D$. antillarum has been widely reported throughout the Caribbean (Lessios et al., 1983). This phenomenon struck the algal study site in Puerto Rico in January 1984 and killed $99 \%$ of the resident $D$. antillarum population within $1 \mathrm{mo}$. Within the same period, macroscopic algae rapidly repopulated the algal plain. While hurricanes and urchin overgrazings are extreme examples of perturbations, their unpredictable occurrence is likely responsible for keeping the offshore algal community in a state of disequilibrium.

Acknowledgements. I thank Drs. Richard Appeldoorn, Gary Breckon, Thomas Tosteson, and Paul Yoshioka for valuable suggestions and criticisms. Ms. Gladys Collazo drafted the figures. Suggestions of 3 anonymous reviewers improved the manuscript.
Almodóvar, L. R., Ballantine, D. L. (1983). Checklist of benthic marine macroalgae plus additional species records from Puerto Rico. Caribb. J. Sci. 19: 7-20

Anonymous (1980). Hurricanes David and Frederic as they concerned Puerto and the Virgin Islands, Aug. 26 - Sept. 5, 1979. National Weather Service

Ball, M. M., Shinn, E. A., Stockman, K. W. (1967). The geological effects of Hurricane Donna in south Florida. J. Geol. 75: 583-597

Ballantine, D. L. (1977). Epiphytes of offshore algal hosts in Puerto Rico and antibiosis of host plant extracts. Ph. D. thesis, University of Puerto Rico, Mayaguez

Ballantine, D. L. (1979). The distribution of algal epiphytes on macrophyte hosts offshore from La Parguera, Puerto Rico. Botanica mar. 22: 107-111

Bray, J. R., Curtis, J. T. (1957). Ordination of the upland forest communities of southern Wisconsin. Ecol. Monogr. 27: 325-349

Breen, P. A., Mann, K. H. (1976). Changing lobster abundance and the destruction of kelp beds by sea urchins. Mar. Biol. 34: $137-142$

Connell, J. H. (1978). Diversity in tropical rain forests and coral reefs. Science, N. Y. 199: 1302-1310

Connell, J. H., Slatyer, R. O. (1978). Mechanisms of succession in natural communities and their role in community stability and organization. Am. Nat. 111: 1119-1144

Emerson, S. E., Zedler, J. B. (1978). Recolonization of intertidal algae: an experimental study. Mar. Biol. 44: 315-324

Everit, B. (1980). Cluster analysis. Halsted Press, New York, p. $25-27$

Foreman, R. E. (1977). Benthic community modification and recovery following intensive grazing by Strongylocentrotus droebachiensis. Helgoländer wiss. Meeresunters. 30: 468-484

Foster, M. S. (1975). Algal succession in a Macrocystis pyrifera forest. Mar. Biol. 32: 313-329

Glynn, P. W., Almodóvar, L. R., Gonzalez, J. G., (1964). Effects of Hurricane Edith on marine life in La Parguera, Puerto Rico. Caribb. J. Sci. 4: 335-345

Goreau, T. F. (1964). Mass expulsion of zooxanthellae from Jamaica reef communities after Hurricane Flora. Science, N.Y. $145: 383-386$ 
John, D. M., Lieberman, D., Lieberman, M. (1977). A quantitative study of the structure and dynamics of benthic subtidal algal vegetation in Ghana (tropical west Africa). J. Ecol. 65: 497-554

Kain, J. M. (1975). Algal recolonization of some cleared subtidal areas. J. Ecol, 63: 739-765

Lessios, H. A., Glynn, P. W., Robertson, D. R. (1983). Mass mortalities of coral reef organism. Science, N.Y. 222: 715

Lubchenco, J., Menge, B. A. (1978). Community development and persistence in a low rocky intertidal zone. Ecol. Monogr. 59: 67-94

Matta, J. L. (1981). The effects of Hurricane David on the benthic algae of a coral reef in La Parguera, Puerto Rico. M. S. thesis, University of Puerto Rico, Mayaguez

Menge, B. A. (1976). Organization of the New England rocky intertidal community: role of predator, competition, and environmental heterogeneity. Ecol. Monogr. 46: 355-393

Morelock, J., Schneidermann, N., Bryant, W. R. (1977). Shelf reefs, southwestern Puerto Rico. Stud. Geol. 4: 17-25

Murray, S. N., Littler, M. N. (1978). Patterns of algal succession in a perturbed marine intertidal community. J. Phycol. 14: 506-512

Neushul, M., Foster, M. S., Coon, D. A., Woessner, J. W., Harger, B. W. W. (1976). An in situ study of recruitment, growth and survival of subtidal marine algae: techniques and preliminary results. J. Phycol. 12: 397-408

Niell, F. X. (1979). Structure and succession in rocky intertidal communities of a temperate intertidal system. J. exp. mar. Biol. Ecol. 36: 185-200

Ogg, J. G., Koslow, J.A. (1978). The impact of Typhoon Pamela (1976) on Guam's coral reefs and beaches. Pacif. Sci. 2: 105-118

Paine, R. T., Levin, S. A. (1981). Intertidal landscapes: disturbance and the dynamics of pattern. Ecol. Monogr. 51: $145-178$

Paine, R. T., Vadas, R. L. (1969). The effects of grazing by sea urchins Strongylocentrotus spp., on benthic algal populations. Limnol. Oceanogr. 14: 710-719
Porter, J. W. (1974). Community structure of coral reefs on opposite sides of the Isthmus of Panama. Science, N. Y. 186: 543-545

Rogers, C. S., Suchanek, T. S., Pecora, F. A. (1982). Effects of Hurricanes David and Frederic (1979) on shallow Acropora palmata reef communities: St. Croix, U.S. Virgin Islands. Bull. mar. Sci. 32: 532-548

Rogers, C. S., Gilnack, M., Fritz, H. C., III. (1983). Monitoring of coral reefs with linear transects: a study of storm damage. J. exp. mar. Biol. Ecol. 66: 285-300

Sears, J. R. (1982). Submarine irradiance and the composition, distribution and structure of a deep water, offshore, benthic algal community at Pigeon Hill, southern Gulf of Maine. Paper read at First Int. Phycol. Congress, St. Johns, Newfoundland, Canada. August 8-14

Sørensen, T. (1948). A method of establishing groups of equal amplitude in plant sociology based on similarity of species content. Biol. Skr., danske Vidensk. Selsk. 5: 1-34

Sousa, W. P. (1979). Experimental investigations of disturbance and ecological succession in a rocky intertidal algal community. Ecol. Monogr. 49: 227-254

Stephenson, W., Endean, R., Bennett, I. (1958). An ecological survey of the marine fauna of low isles, Queensland. Aust. J. mar. Freshwat. Res. 9: 261-318

Stoddart, D. R. (1970), Coral reefs and islands and catastrophic storms. In: Steers, J.A. (ed.) Applied coastal geomorphology. McMillan Co, London, p. 155-197

Tsuda, R. T., Kami, N. T. (1973). Algal succession in artificial reefs in a marine lagoon environment in Guam. J. Phycol. 9: 260-264

Woodley, J. D., Chornesky, E. A., Clifford, P. A., Jackson, J. B. C., Kaufmann, L. S., Knowlton, N. K., Lang, J. C., Pearson, M. P., Porter, J. W., Rooney, M. C., Rylaarsdam, K. W., Tunnicliffe, V. J., Wahle, C. M., Wulff, J. L., Curtis, A. S. G., Dallmeyer, M. D., Jupp, B. P., Koehl, M. A. R., Neigel, J., Sides, E. M. (1981). Hurricane Allen's impact on Jamaican coral reefs. Science, N. Y. 214: 749-755 